\title{
CISOVKA - THE RELIC POPULATION OF ABIES ALBA AND ITS RELATIONSHIP TO MAN-MADE SILVER-FIR STANDS IN BIAŁOWIEŻA PRIMEVAL FOREST
}

\author{
LEON MEJNARTOWICZ \\ Institute of Dendrology, Polish Academy of Sciences \\ 62-035 Kórnik, Poland
}

(Received: January 2, 1996. Accepted: May 24, 1996)

\begin{abstract}
In Białowieża Primeval Forest, in 1823 Stanisław Górski discovered on the Cisovka Hag, a relic population of European silver-fir (Abies alba Mill.). This population is isolated and most away, $120 \mathrm{~km}$ to the North-East, from the border of European-silver-fir distribution. Besides the natural population Cisovka, there are also man-made silver fir stands and clumps in the Polish and Belorussian part of Białowieża Primeval Forest. In the Polish part there are four such artificial stands. If the seed-producing silver-fir stands really originated from the Cisovka population, then they are a very valuable part of the declining population and an easy accessible seed source. However, if these populations were introduced to the Białowieża Primeval Forest, then they are a potential source of dangerous genetic pollution of the Cisovka population.

The relationship of the genetic structure of the Cisovka population to man-made silver-fir-stands in Białowieża Forest was investigated with the help of 17 loci of 11 enzyme systems. Genetic diversity of Cisovka population is characterized by the smallest mean number of alleles per locus ( $M a l=1.353$, includes all loci studied and per polimorphic locus Malp $=2.00$ ). In Cisovka population there is very low-grade of polimorphic loci $(P p=11.765$ with the mean 37.255 for all studied populations). Expected heterozygosity, $\mathrm{He}=0.079$ revealed very low-grade of genetic diversity in the population. The observed heterozygosity $(\mathrm{Ho}=0.123)$ was similar to this characterictic in other populations. A dendrogram based on Neis genetic distance coefficient (D) among 9 silver-fir populations was constructed. Cisovka in the UPGMA dendrogram is a distinct population separated from other ones by a very great genetic distance $(D=0.06)$. Also two man-made silver-fir $(B 1$ and $B 2)$ stands are separated from others. Only populations B3 and B4 are combined into one subgroup linked to the population Tomaszów Lubelski.

Basing on the received results one should decide that all the four studied artificial stands were introduced to Białowieża Primeval Forest from beyond of this geographical regions. There is some reason to assume (on the GDH2 allele frequency) that man-made silver-stands in compartments $453 \mathrm{Aa}$ and $498 \mathrm{Cg}$ are of eastern provenance. It is rather certain that these stands are not of offspring of Cisovka populations
\end{abstract}

KEY WORDS: Abies alba, isozymes, preservation.

\section{INTRODUCTION}

In Białowieża Primeval Forest, the only natural lowland forest remaining in Europe, on the expansive bogs, called "Dikij Nikor", in 1823 Stanisław Górski (S.G. 1829), discovered on the Cisovka Hag, a relic population of European silver-fir (Abies alba Mill.). At the initiative of Władysław Szafer (1920a) the Cisovka Hag was protected as "Cisówka Reserve".

The uniqueness of the Cisovka silver-fir population is in its locality. This population is isolated and most distand away, $120 \mathrm{~km}$ to the North-East, from the border of European-silver-fir distribution (Fig. 1 and 2). Górski (1829) wrote These trees are growing in only one place in the Białowieża Primeval Forest..., only on the range called Cisówka surrounded with swamps. According to Górski it is a natural population. Trees there were smaller than in the area of close distribution of silver-fir stands. The biggest tree was 2 feet in diameter (about $61 \mathrm{~cm}$ ) at the bottom (Górski l.c.).
On the Hag the silver-fir is growing with Picea abies, Betula pendula, Populus tremula, Tilia cordata, Fraxinus excelsior, Ulmus effusa, Ulmus scabra, Quercus robur composing a mixed forest of the Quercion robori-petreae alliance. We confirmed the same forest composition in 1995.

Since 1945 the Cisówka Reserve belongs to the Belorussian part of Białowieża Primeval Forest and, is called "Cisovka" (Shkutko and Martinovitch 1967) though also in use are the names: "Tisovka", "Tisovik" and "Cisovik".

The relationship of the date to the number of silver-fir trees on Cisovka Hag presented below, show us that it is a declining population, which could either go through a "bottle neck" and increase in number of trees in the population or completely disappear.

Currently the number of the silver-fir trees in the population attained a critical value. In February 1995 we counted only 20 trees. There were many small seedlings, 1-2 years old, and a complete lack of older undergrowth. This characteristic of the Cisovka population was noted by Błoński et al. (1888) and 
later by Szafer (1920), Shkutko and Martinovitch (1967), Korczyk and Chilimoniuk (1993).

Though in this population there are 20 silver-fir trees, the number of trees simultaneously producing female and male gametes is probably lower because on one tree we observed only female flower buds. However cones and seeds are produced abundantly. The evidence for this is on the cone-bearing branches and branches numerous rachises of scattered cones and seeds lying on the dense undergrowth plants. Seeds collected in February and sowed in a phytotron, germinated at $15 \%$. The tree crowns are sound, without the symptoms of injury from environmental pollutants. There is however visible injury to needles caused by insects.

Besides the natural population Cisovka, there are also man - made silver fir stands and clumps in the Polish and Belorussian part of Białowieża Primeval Forest. In the Polish part there are four such artificial stands. Two of them were established in about 1928 (Gunia and Kowalski 1968). Korczyk and Chilimoniuk (1993) also maintain that these stands originate from the Cisovka Reserve. This is however an a priori statement. For all four man-made silver-fir stands, mentioned in Table 2, there are no data concerning provenance. All thece stands are of different ages. In the oldest plantings there is natural regeneration and trees are producing female and male gametes. These gametes could be transferred over long distances.
If the seed-producing silver-fir stands really originated from the Cisovka population, then they make a very valuable part of the declining population and an easily accessible seed source. However, if these populations were introduced to the Białowieża Primeval Forest, then they are a potential source of dangerous genetic pollution of the Cisovka population and such stands will be a good example of synanthropisation of the Primeval Forest.

\section{Working hypothesis}

The aim of the investigations was to characterize the genetic variation of the Cisovka population and its relationship to four of man-made silver-fir stands growing in the Polish Białowieża Primeval Forest. If these man-made stands are of Cisovka provenance, then they should be characterized by a reciprocal small genetic distance and similar genetic structure. If these stands are not of Cisovka provenance then they will be a good example of the synanthropisation of the Primeval Forest.

\section{PLANT MATERIAL}

\section{Cisovka declining population}

Górski (1829) in his description of Cisovka Population did not give the number of silver-fir trees. Błoński et al. (1888)

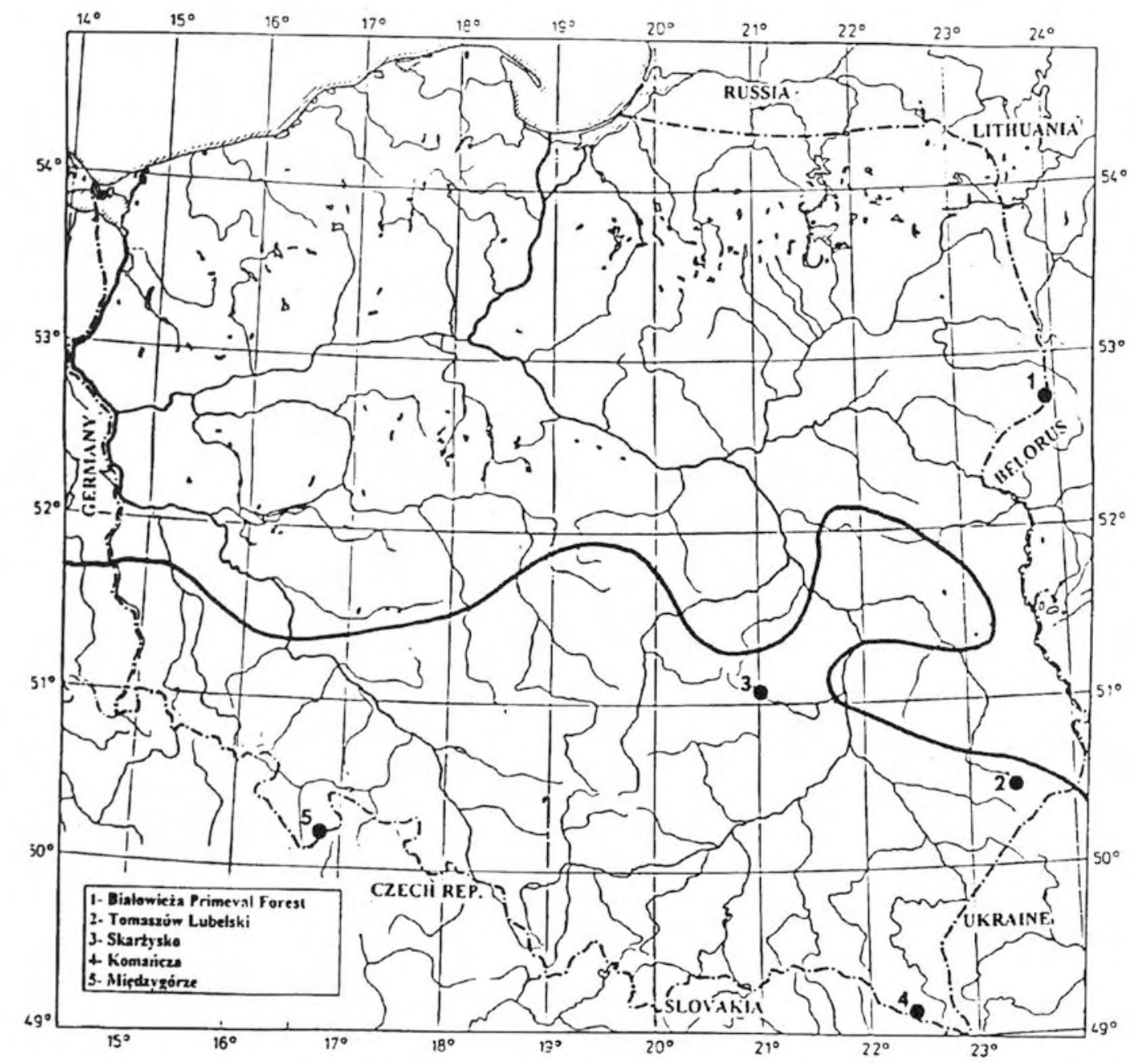

Fig. 1. North-eastern border of European-silver-fir distribution. Geographic location of the provenance seed collection sites: 1-5. 


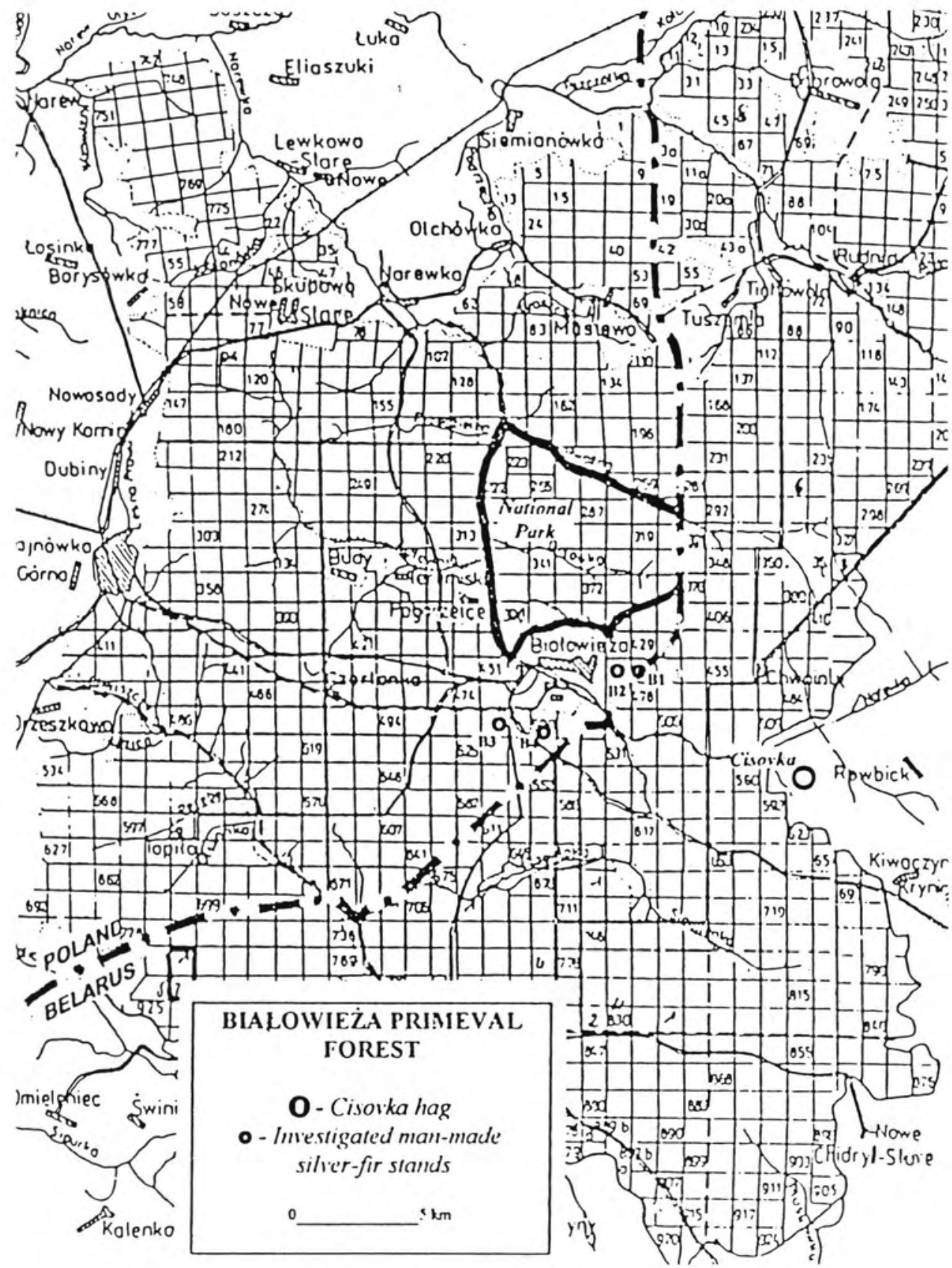

Fig. 2. Location of man-made silver-fir stands and the Cisovka population in the Białowieża Primeval Forest. sixty years later wrote that on Cisovka Hag he found not more than several hundred silver-fir trees with diameters of 13-15 cm "about mans high". In 1920 the Polish Committee for Nature Protection (Professors: W. Szafer, S. Hryniewiecki, Dr. S. Kulczyński and Mr. J. Lilpop) stated that on Cisovka Hag there were growing silver-fir trees of different-age, but not more than 100 trees with a diameter above $12 \mathrm{~cm}$. The oldest tree was more than 200 hundred years old with a d.b.h. of $58 \mathrm{~cm}$ and $33,5 \mathrm{~m}$ high. Paczoski (1930) who counted trees with d.b.h. above $7 \mathrm{~cm}$, recorded 255 silver-fir trees with a d.b.h. 7-38 cm. Thirty-six years later there remained only 35 trees with 25-77 cm d.b.h. and $33 \mathrm{~m}$ in height growing on area of 2 ha (Shkutko and Martinovitch 1956). These authors also remarked the lack of trees aged 25-100 years.

In 1956 the expansive bogs surrounding Cisovka Hag were drained and put under grass cultivation. The water relations were changed drastically at Cisovka Hag. As a consequence of a wind storm in 198312 trees fell, so there remained only 23 silver-fir trees (Budnichyenko et al. 1987). Ten years later there were only 20 trees and they were $110-155$ years old (Korczyk and Chilimoniuk 1993). Therefore one can assume that this is the second generation to that described by Górski in 1826. In February 1995 we also counted 20 trees (Fig. 3). For all trees d.b.h. and height were measured (Table. 1).

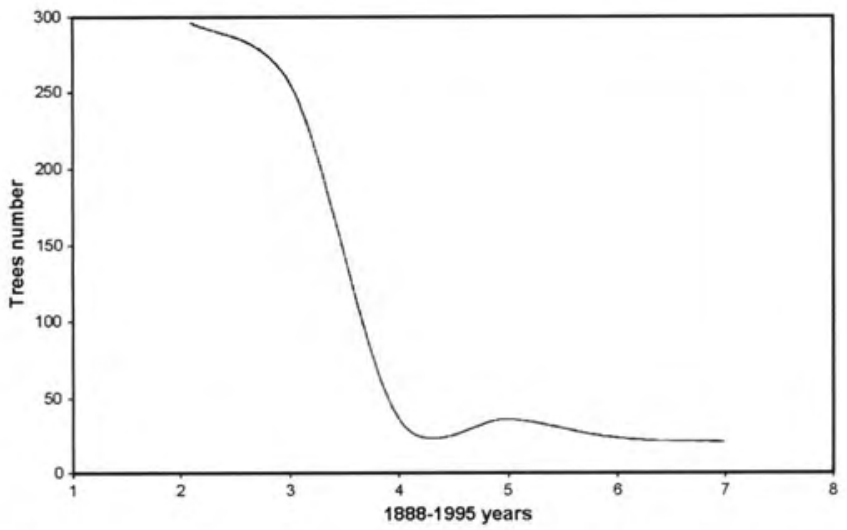

Fig. 3. Declining curve of the Abies alba Cisovka population from 1888-1995. 
TABLE 1. Biometrical data of silver-fir trees from the Cisovka Reserve in 1995.

\begin{tabular}{ccclc}
\hline No. & Tree code & DBH & High & Remarks \\
\hline 1. & $45-1597$ & 60 & 35.5 & Buds coll. Grafted \\
2. & $45-1598$ & 55 & 30.5 & Buds coll. Grafted \\
3. & $45-1599$ & 69 & 38.5 & Buds coll. Grafted \\
4. & $45-1600$ & 72 & 38.5 & Buds coll. Grafted \\
5. & $45-1601$ & 87 & 37 & Buds coll. Grafted \\
6. & $45-1602$ & 51 & 37 & Buds coll. Grafted \\
7. & $45-1603$ & 74 & 35.5 & Buds coll. Grafted \\
8. & $45-1604$ & 50 & 31.5 & Buds coll. Grafted \\
9. & $45-1605$ & 55 & 31.5 & Buds coll. Grafted \\
10. & $45-1606$ & 58 & 37 & Buds coll. Grafted \\
11. & $45-1607$ & 60 & 34 & Buds coll. Grafted \\
12. & - & 70 & 35 & - \\
13. & - & 69 & 35 & - \\
14. & - & 82 & 35 & - \\
15. & - & 84 & 38.5 & - \\
16. & - & 85 & 34 & - \\
17. & - & 87 & 36 & - \\
18. & - & 68 & 34 & - \\
19. & - & 58 & 33 & \\
20. & - & 43 & 28 & \\
\hline Arithmetic average (SD) & $69(13)$ & $35(2.8)$ & \\
\hline
\end{tabular}

\section{Analytical material}

All shoots for laboratory analyses were collected in $\mathrm{Fe}$ bruary, at air temperatures of $-2^{\circ}$ to $+2^{\circ} \mathrm{C}$ and transported in an icebox to the laboratory and stored at $-70^{\circ} \mathrm{C}$ until analysis time. To obtain a representative sample of the studied populations, $55 \%$ of trees were sampled for Cisovka, $34 \% ; 47 \%$ for stands in compartments $453 \mathrm{Aa}$, and $498 \mathrm{Cg}$ of Białowieża Forest Inspectorates. Small clumps of silver-fir trees growing in compartments $452 \mathrm{Bd}$ and $500 \mathrm{Cj}$ were sampled in $100 \%$.

For comparison we also collected material from 15 trees of 4 populations scattered throughout the area of silver-fir distribution in Poland. The South-East region was represented by the Komańcza Population (Bieszczady Mts.), the North-East by Tomaszów Lubelski, the Central (Swiętokrzyskie Mts.) by Skarżysko and West-South (Sudety Mts.) by Międzygórze Population. To ensure comparability to the Białowieża stands, all the sampled trees were about 25 years old. For the Międzygórze population seed samples from 18 trees were also analyzed.

To determine the differences between isoenzymes originating from different tissues homogenates of male and female and vegetative buds were analyzed separately.

Terminal buds of shoots from Cisovka were grafted to 5year-old silver-fir seedlings in Zwierzyniec Experimental Forest by Kórnik (Fig. 4). This way over $50 \%$ of the Cisovka population will be protected from extinction.

All silver-fir stands in the Polish part of the Primeval Forest are located in the Białowieża Forest Inspectorate. The oldest - largest stand is located in compartment $453 \mathrm{Aa}$ of Stoczek Forestry. There are about 80 trees of different age. The oldest trees are 65 years old and are producing flower buds abundantly. Shoots were collected from all trees both from the upper layer and from a part of the undergrowth. All together 27 trees were sampled and marked with code numbers from 04-1541 to 04-1567 (Table 2). Both stands appear as though they originated from sowing.

The second stand neighboring 452Bd compartment is much smaller. It is a group of 9 trees also of different age, but only two are old. Material was collected from all trees and coded from 04-1568 to 04-1576. The two other silver-fir stands are in the Podolany Forest. In compartment $498 \mathrm{Cg}$ there are about 30 trees. This stand appears to have originated from seedlings. Many trees are of similar age, ca. 60 years. Shoots were collected from 16 trees coded with numbers from 041577 to $04-1592$. On trees Nos.: 1577,1580 and 1580 there were plenty of male and female flowers. In compartment $500 \mathrm{Cj}$ only 4 trees were found. One of them was about 60 years old with many flower buds. The remaining 3 trees are of different age and much younger (Table 2).

\section{RESULTS}

\section{Isozyme analysis}

The enzymes were separated by horizontal starch gel electrophoresis in discontinuous buffer systems after Poulik (1957) and Ridgeway et al. (1970). Gel concentration was $11.5 \%$, voltage distribution $25 \mathrm{~V} / \mathrm{cm}$, and bridge distance 9 $\mathrm{cm}$. Buds and megagametophytes were homogenized and enzymes were separated from crude homogenate. Buffers systems for enzyme stains and genetic interpretation were used after Bergmann and Kownatzki (1988), Cheliak and Pitel (1989), Hussendoerfer et al. (1995), Konnert (1992), Longauer (1994), Mejnartowicz (1979), Mejnartowicz and Lewandowski (1984). The following enzymatic loci were studied:

Glutamate dehydrogenase - 1.4.1.2 (Gdh-1), Phosphoglucomutase - 5.4.2.2 (Pgm-1, -2),

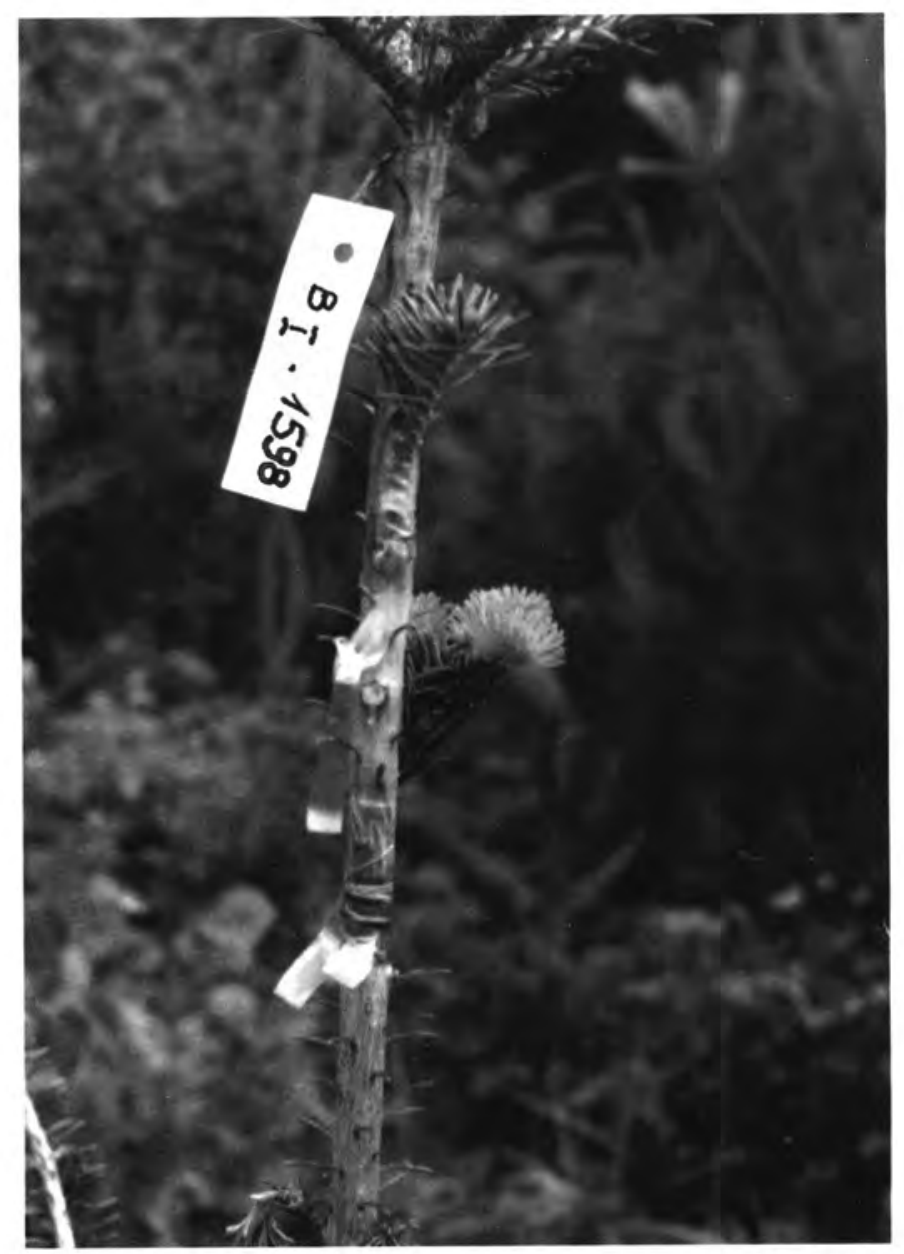

Fig. 4. Vegetative propagated Cisovka silver-fir tree $\mathrm{nr}$ 45-1598 in Institute of Dendrology - Experimental Forest Zwierzyniec. 
TABLE 2. Biometrical data, DBH $[\mathrm{cm}]$ and $\mathrm{H}[\mathrm{m}]$ for four artificial stands in the Białowieża Forest District.

\begin{tabular}{|c|c|c|c|c|c|c|c|c|c|c|c|}
\hline \multicolumn{3}{|c|}{ Forestry Stoczek $453 \mathrm{Aa}$} & \multicolumn{3}{|c|}{ Forestry Stoczek 452 Bd } & \multicolumn{3}{|c|}{ Forestry Podolany $498 \mathrm{Cg}$} & \multicolumn{3}{|c|}{ Forestry Podolany $500 \mathrm{Cj}$} \\
\hline $\begin{array}{l}\text { Tree } \\
\text { code }\end{array}$ & $\varnothing$ & $\mathrm{H}$ & $\begin{array}{l}\text { Tree } \\
\text { code }\end{array}$ & $\varnothing$ & $\mathrm{H}$ & $\begin{array}{l}\text { Tree } \\
\text { code }\end{array}$ & $\varnothing$ & $\mathrm{H}$ & $\begin{array}{l}\text { Tree } \\
\text { code }\end{array}$ & $\varnothing$ & $\mathrm{H}$ \\
\hline 1541 & 35 & 26 & 1568 & 16 & 25 & 1577 & 29 & 23 & 1593 & 32 & 22 \\
\hline 1542 & 38 & 23 & 1569 & 25 & 20 & 1578 & 14 & 11 & 1594 & 10 & 8 \\
\hline 1543 & 28 & 22 & 1570 & 15 & 11 & 1579 & 33 & 20 & 1595 & 14 & 14 \\
\hline 1544 & 16 & 9 & 1571 & 2 & 2 & 1580 & 23 & 17 & 1595 & 15 & 14 \\
\hline 1545 & 24 & 19 & 1572 & 6 & 3 & 1581 & 16 & 12 & & & \\
\hline 1546 & 37 & 25 & 1573 & 9 & 5 & 1582 & 18 & 15 & & & \\
\hline 1547 & 20 & 17 & 1574 & 10 & 7 & 1583 & 21 & 17 & & & \\
\hline 1548 & 26 & 21 & 1575 & 6 & 4 & 1584 & 10 & 6 & & & \\
\hline 1549 & 20 & 17 & 1576 & 5 & 4 & 1585 & 13 & 5 & & & \\
\hline 1550 & 19 & 17 & & & & 1586 & 17 & 10 & & & \\
\hline 1551 & 12 & 11 & & & & 1587 & 26 & 16 & & & \\
\hline 1552 & 26 & 19 & & & & 1588 & 19 & 17 & & & \\
\hline 1553 & 19 & - & & & & 1589 & 26 & 19 & & & \\
\hline 1554 & 11 & - & & & & 1590 & 34 & 22 & & & \\
\hline 1555 & 28 & 23 & & & & 1591 & 17 & 20 & & & \\
\hline 1556 & 12 & 9 & & & & 1592 & 17 & 17 & & & \\
\hline 1557 & 23 & 20 & & & & & & & & & \\
\hline 1558 & 18 & 3 & & & & & & & & & \\
\hline 1559 & 17 & 6 & & & & & & & & & \\
\hline 1560 & 20 & 16 & & & & & & & & & \\
\hline 1561 & 26 & 17 & & & & & & & & & \\
\hline 1562 & 27 & 20 & & & & & & & & & \\
\hline 1563 & 25 & 18 & & & & & & & & & \\
\hline 1564 & 30 & 23 & & & & & & & & & \\
\hline 1565 & 4 & 3 & & & & & & & & & \\
\hline 1566 & 3 & 3 & & & & & & & & & \\
\hline 1567 & 5 & 3 & & & & & & & & & \\
\hline $\begin{array}{l}\text { Arthm. } \\
\text { mean }\end{array}$ & 21 & 17 & & 10 & 9 & & 21 & 15 & & 18 & 15 \\
\hline SSD & 9 & 7 & & 7 & 8 & & 7 & 5 & & 10 & 6 \\
\hline $\mathrm{R}$ & 34 & 24 & & 23 & 23 & & 7 & 7 & & 22 & 14 \\
\hline
\end{tabular}

Phosphoglucose isomerase - 5.3.1.9 (Pgi-1, -2), Superoxide dismutase - 1.15.1.1 (Sod -1)

Menandione reductase -1.6.99.2 (Men-1, -2), 6-Phosphogluconate dehydrogenase - 1.1.1.44

(6-Pgdh -2), Isocitrate dehydrogenase -1.1.42 (Idh-1, -2), Fluorescence esterase - 3.1.1.2 (Fle -1),

Glutamate oxalacetate transaminase - 2.6.1.1 (Got-1, -2), Leucine aminopeptidase - 3.4.11.1 (Lap -1, -2), Esterase 3.1.1.1 (Est -3).

\section{Genetic variation and diversity analyses}

The relationship of the genetic structure of the Cisovka population to man-made silver-fir-stands in Białowieża Forest was investigated with the help of 17 loci of 11 enzyme systems.

The genetic control and the mode of inheritance of these enzyme systems were analyzed on large half-sib seed samples collected from individual trees of Międzygórze and LądekZdrój Sudeten provenance (Mejnartowicz et al. 1994). 
Each analyzed enzyme system had similar enzyme patterns independent of the tissue from which it was extracted - diploid from buds or haploid from megagametophytes, with one exception - esterase enzyme. This enzyme pattern was well visible only in electrophoregrams of bud tissue. There were also differences in enzyme activity tissue originated from different bud types and the megagametophyte.

Enzymes exhibiting no variation are called "monomorphic" others showing minimal variation are called "semimonomorphic" and the other variable ones are called "polymorphic".

\section{Monomorphic loci}

In the investigated populations allelic variability was not found at 5 loci: Mnr 1 and Mnr 2 of menandione reductase, Sod of superoxide dismutase, Fle of fluorescent esterase and Got 2 of glutamate oxalacetate transaminase. Some of these loci revealed allelic variation only in populations of the western part of species distribution (e.g. Mnr2 and Got2 where these loci possess 3 alleles each). The other loci are variable only in populations of the eastern part of the species distribution such as Gdh, which was monomorphic in western populations.

\section{Semimonomorphic loci}

Some enzyme loci are coding alleles that occur very rarely only in one or few populations. Such alleles could be helpful in establishing population relatedness, and analyses of postglacial migration. In considering the genetic similarity between the Cisovka natural population and the artificial silverfir stands of this species in Białowieża Forest we assume that they are the F1 generation of Cisovka and as such could possess rare alleles existing in this population, and if unrelated genetically should not possess the rare alleles existing in $\mathrm{Ci}$ sovka.

Because the Cisovka population is an inland, geographically isolated population one can this assume that rare alleles found in this and artificial populations in Białowieża Forest will indicate a close genetic affinity.

Glutamate dehydrogenase - Gdh. This is one of the enzyme systems with very small variation among needle-bearing trees and in the genus Abies. In Norway spruce Gdh variation was found at the level of 1:10.000 trees. This however allowed to localize Gdh locus on the same chromosome coding for the Idh enzyme (Lewandowski and Mejnartowicz 1994).

Hussendörfer at al. (1995) found no Gdh variation in silverfir populations from southern and western parts of Europe. Yet Schröder claims that Gdh in Germany silver-fir populations consists of alleles. Longauer (1994) similarly found 2 alleles of $\mathrm{Gdh}$ in northern and south-eastern populations of silver-fir from Poland. The frequency for the Gdh-2 allele was 0.004 and 0.008 for the eastern and south-eastern populations, respectively. We found the maximum frequency for the silver-fir Gdh2 allele in the Cisovka population. There Gdh2 reached a frequency of 0.04 . No single population from the south-east range of Abies alba, studied by Longauer (l.c.) is similar with respect to the Gdh2 allele to the Cisovka population. Two of four artificial silver-fir stands in compartments $453 \mathrm{Aa}$ and $498 \mathrm{Cg}$ of the Białowieża Forest possessed a high Gdh2 frequency: 0.018 and 0.031 respectively. All other populations investigated by us are monomorphic with respect to the Gdh locus.

One may suppose that the Gdg2 allele possesses clinal variation in frequency increasing from south-west to north-east, with a maximum in the inland Cisovka population.
Phosphoglucomutase Pgm. This enzyme has two loci (Mejnartowicz et al. 1994), one of which, Pgml is semimonomorphic. In German silver-fir populations, Konnert (1992) found no variation at locus Pgm1. In this study locus Pgm1 has 2 alleles with the same frequency of $0.03 \%$ in the Skarżysko population and in the Białowieża $498 \mathrm{Cg}$ compartment. This allel Pgm1-2 was not found in the Cisovka population (Table 3.).

Phosphoglucose isomerase Pgi is encoded by two loci Pgil and Pgi 2 (Mejnartowicz et al. 1994). Both loci possessed allelic variation only in two artificial stands of the neighboring 453Aa and 452Bd compartments of Białowieża, where allel Pgil-2 reached high and similar frequencies of $18 \%$ and $17 \%$, respectively. Likewise the allele Pgi2-2 was found only in these stands. This allele had a frequency of 0.148 for stand into compartment $453 \mathrm{Aa}$ and 0.333 for compartment $452 \mathrm{Bd}$ (Table 3). Such high frequency of rare alleles in the stands from compartments $453 \mathrm{Aa}$ and $452 \mathrm{Cg}$ and the lack of these alleles in other populations suggests that these neighboring populations are genetically related and that they are not related to the Cisovka population. This hypotheses is also supported by Neis genetic distance analysis (Fig. 5) based on the frequency of all studied alleles and by the frequencies of other alleles mentioned below.

\section{Polimorphic loci}

To this group belong loci coding enzyme: Pgm2, 6-Pgdh, Idh1, Idh2, Lap1, Lap2, and Est3.

Phosphoglucomutase Pgm2, this is variable loci with two loci (Mejnartowicz et al. 1994). In all studied populations the allele Pgm2-1 reached a much higher frequency (from $\mathrm{p}=$ 0.750 to $\mathrm{p}=1$ ) than $\mathrm{Pgm} 2-2$ with a frequency from 0 to 0.250 (Table 3.). And here the Cisovka population is an exception. Allele Pgm2-2 is present at a higher frequency ( $\mathrm{p}=$ $0.591)$ then Pgm2-1 ( $\mathrm{p}=0.409)$.

6-Phosphogluconate dehydrogenase (6-Pgdh1 ) in megagamethophytes of Sudeten populations is an enzyme a coded in two loci (Shröder 1989) with three alleles each (Mejnartowicz et al. 1994). In this study only locus 6-Pgdhl was investigated. This locus has two triple-banded variants manifested only in the artificial population from Białowieża compartment 500Cj and the Tomaszów Lubelski and Skarżysko populations.

Isocitrate dehydrogenase (Idh). Gels stained for Idh showed two zones of activity with 3 alleles each in Sudeten populations (Mejnartowicz and Lewandowski 1995, Mejnartowicz et al. 1994). Silver-fir populations in western Europe are more variable in Idh1. Shröder (1989) and Hussedörfer et al. (1995) found 4 alleles in Idh1 and 5 alleles in Idh2. Both Idh loci were invariant in the Cisovka population (Table 3).

In all studied populations the Idh1-2 allele was not found. Three of four artificial silver-fir stands in Białowieża Forest, however, are variable in Idh2 loci. The allele Idh2-2 was manifested at a high frequency in all populations but not in Cisovka which lacked this allele (Table 3). This trait strongly distinguishes the Cisovka population from the others.

Leucine aminopeptidase (Lap). This enzyme system is controlled by two loci (Mejnartowicz 1979). The Lap1 locus is coding in the fastest migrating zone of enzymes identical to the aminopeptidase Ap1 locus and the locus Lap2 is identical to Ap3 (Hussendörfer et al. 1995).

Lap1 in the megagametophytes of the Lądek Zdrój population from Sudeten has 3 alleles (Mejnartowicz et al. 1994) and in populations from Western Europe 6 alleles were found (Hussendörfer et al. 1995). In bud tissue of our material only 
TABLE 3. Silver-fir population allele frequencies.

\begin{tabular}{|c|c|c|c|c|c|c|c|c|c|}
\hline $\begin{array}{c}\text { Population: } \\
\text { Allele }\end{array}$ & $\begin{array}{l}\text { Tomasz. } \\
\text { Lubelski }\end{array}$ & Skarży. & Komań & Międzyg & $\begin{array}{c}\text { Białow. } \\
453 \mathrm{Aa}\end{array}$ & $\begin{array}{l}\text { Białow. } \\
\text { 452Bd }\end{array}$ & $\begin{array}{c}\text { Białow. } \\
498 \mathrm{Cg}\end{array}$ & $\begin{array}{l}\text { Białow. } \\
500 \mathrm{Cj}\end{array}$ & Cisovka \\
\hline \multicolumn{10}{|l|}{ 1). Gdh } \\
\hline 1 & 1 & 1 & 1 & 1 & 0.9815 & 1 & 0.9688 & 1 & 0.9545 \\
\hline 2 & 0 & 0 & 0 & 0 & 0.0185 & 0 & 0.0313 & 0 & 0.0455 \\
\hline \multicolumn{10}{|l|}{ 2). Pgm 1} \\
\hline 1 & 1 & 0.9667 & 1 & 1 & 1 & 1 & 0.9688 & 1 & 1 \\
\hline 2 & 0 & 0.0333 & 0 & 0 & 0 & 0 & 0.0313 & 0 & 0 \\
\hline \multicolumn{10}{|l|}{ 3). Pmg 2} \\
\hline 1 & 0.8667 & 0.8333 & 0.8667 & 0.9583 & 0.963 & 1 & 0.875 & 0.75 & 0.4091 \\
\hline 2 & 0.1333 & 0.1667 & 0.1333 & 0.0417 & 0.037 & 0 & 0.125 & 0.25 & 0.5909 \\
\hline \multicolumn{10}{|l|}{ 4). Pgi 1} \\
\hline 1 & 1 & 1 & 1 & 1 & 0.8148 & 0.8333 & 1 & 1 & 1 \\
\hline 2 & 0 & 0 & 0 & 0 & 0.1852 & 0.1667 & 0 & 0 & 0 \\
\hline \multicolumn{10}{|l|}{ 5). Pgi 2} \\
\hline 1 & 1 & 1 & 1 & 1 & 0.8519 & 0.6667 & 1 & 1 & 1 \\
\hline 2 & 0 & 0 & 0 & 0 & 0.1481 & 0.3333 & 0 & 0 & 0 \\
\hline 6). Sod & 1 & 1 & 1 & 1 & 1 & 1 & 1 & 1 & 1 \\
\hline \multicolumn{10}{|l|}{ 7). Men 1} \\
\hline 1 & 1 & 1 & 1 & 1 & 1 & 1 & 1 & 1 & 1 \\
\hline 8). Men 2 & 1 & 1 & 1 & 1 & 1 & 1 & 1 & 1 & 1 \\
\hline \multicolumn{10}{|l|}{ 9). 6-Pgdh } \\
\hline 1 & 0.8667 & 0.9667 & 1 & 1 & 1 & 1 & 1 & 0.8750 & 1 \\
\hline 2 & 0.1333 & 0.0333 & 0 & 0 & 0 & 0 & 0 & 0.1250 & 0 \\
\hline \multicolumn{10}{|l|}{ 10). Idh 1} \\
\hline 1 & 0.6667 & 0.7 & 0.7 & 0.7917 & 1 & 0.9444 & 0.8438 & 0.75 & 1 \\
\hline 2 & 0 & 0 & 0 & 0 & 0 & 0 & 0 & 0 & 0 \\
\hline 3 & 0.3333 & 0.3 & 0.3 & 0.2083 & 0 & 0.0556 & 0.1563 & 0.25 & 0 \\
\hline \multicolumn{10}{|l|}{ 11). Idh 2} \\
\hline 1 & 0 & 0 & 0 & 0 & 0.0370 & 0.0556 & 0 & 0 & 0 \\
\hline 2 & 0.3667 & 0.2333 & 0.3667 & 0.2500 & 0.1852 & 0.4444 & 0.5 & 0.3750 & 0 \\
\hline 3 & 0.6333 & 0.7667 & 0.6333 & 0.7500 & 0.7778 & 0.5000 & 0.5 & 0.6250 & 1 \\
\hline \multicolumn{10}{|l|}{ 12). Fle } \\
\hline 1 & 1 & 1 & 1 & 1 & 1 & 1 & 1 & 1 & 1 \\
\hline \multicolumn{10}{|l|}{ 13). Got 1} \\
\hline 1 & 0.0667 & 0 & 0 & 0 & 0 & 0 & 0 & 0 & 0 \\
\hline 2 & 0.9333 & 1 & 1 & 1 & 1 & 1 & 1 & 1 & 1 \\
\hline \multicolumn{10}{|l|}{ 14). Got 2} \\
\hline 1 & 1 & 1 & 1 & 1 & 1 & 1 & 1 & 1 & 1 \\
\hline \multicolumn{10}{|l|}{ 15). Lap 1} \\
\hline 1 & 0 & 0.0333 & 0 & 0 & 0 & 0 & 0 & 0.125 & 0.0455 \\
\hline 2 & 1 & 0.9667 & 1 & 1 & 1 & 1 & 1 & 0.875 & 0.9545 \\
\hline \multicolumn{10}{|l|}{ 16). Lap 2} \\
\hline 1 & 0.2 & 0.3 & 0.1667 & 0.2500 & 0.2222 & 0.2222 & 0.4688 & 0.3750 & 0 \\
\hline 2 & 0.7 & 0.4333 & 0.6667 & 0.3750 & 0.5926 & 0.7222 & 0.3750 & 0.3750 & 0.9545 \\
\hline 3 & 0.1 & 0.2667 & 0.1333 & 0.2917 & 0.1111 & 0 & 0.1563 & 0.2500 & 0.0455 \\
\hline 4 & 0 & 0 & 0.0333 & 0.0833 & 0.0741 & 0.0556 & 0 & 0 & 0 \\
\hline \multicolumn{10}{|l|}{ 17). Est 3} \\
\hline 1 & 0.2667 & 0.7 & 0.5667 & 0.5 & 0.6667 & 0.8889 & 0.3438 & 0.25 & 0.1364 \\
\hline 2 & 0.6667 & 0.2333 & 0.4333 & 0.375 & 0.3333 & 0.1111 & 0.5 & 0.75 & 0.3636 \\
\hline 3 & 0.6667 & 0 & 0 & 0.125 & 0 & 0 & 0.0938 & 0 & 0.5 \\
\hline 4 & 0 & 0.0667 & 0 & 0 & 0 & 0 & 0.0625 & 0 & 0 \\
\hline
\end{tabular}


TABLE 4. Genetic parameters of nine Abies alba populations. Abbreviations decryption in text.

\begin{tabular}{|c|c|c|c|c|c|c|c|}
\hline \multirow[t]{2}{*}{ Population } & \multirow[t]{2}{*}{$\mathbf{N}$} & \multirow[t]{2}{*}{ Mal } & \multirow[t]{2}{*}{ Malp } & \multicolumn{2}{|c|}{$\%$ of loci polim. } & \multirow[t]{2}{*}{ Ho } & \multirow[t]{2}{*}{$\mathrm{He}$} \\
\hline & & & & $>99 \%$ & $>95 \%$ & & \\
\hline $\begin{array}{l}\text { Tomaszów Lub. } \\
\text { Skarżysko } \\
\text { Komańcza } \\
\text { Międzygórze } \\
\text { Białowieża, } 453 \mathrm{Aa} \\
\text { Białowieża, 452Bd } \\
\text { Białowieża, } 498 \mathrm{Cg} \\
\text { Białowieża, 498Cg } \\
\text { Cisovka }\end{array}$ & $\begin{array}{r}15 \\
15 \\
15 \\
15 \\
27 \\
9 \\
16 \\
4 \\
11\end{array}$ & $\begin{array}{l}1.529 \\
1.588 \\
1.412 \\
1.471 \\
1.529 \\
1.412 \\
1.588 \\
1.471 \\
1.353 \\
\end{array}$ & $\begin{array}{l}2.286 \\
2.250 \\
2.400 \\
2.600 \\
2.286 \\
2.167 \\
2.429 \\
2.143 \\
2.200 \\
\end{array}$ & $\begin{array}{l}41.176 \\
47.059 \\
29.412 \\
29.412 \\
41.176 \\
35.294 \\
41.176 \\
41.176 \\
29.412 \\
\end{array}$ & $\begin{array}{l}41.176 \\
29.412 \\
29.412 \\
23.529 \\
29.412 \\
35.294 \\
29.412 \\
41.176 \\
11.765 \\
\end{array}$ & $\begin{array}{l}0.137 \\
0.141 \\
0.106 \\
0.118 \\
0.118 \\
0.150 \\
0.140 \\
0.176 \\
0.123 \\
\end{array}$ & $\begin{array}{l}0.143 \\
0.138 \\
0.124 \\
0.123 \\
0.135 \\
0.144 \\
0.138 \\
0.158 \\
0.079\end{array}$ \\
\hline Mean & & 1.484 & 2.307 & 37.255 & 30.065 & 0.129 & 0.131 \\
\hline
\end{tabular}

the alleles Lap1-1 and Lap-2 were found in three populations. Very similar frequencies of Lap1-1 alleles were found in two populations: Cisovka and Skarżysko (0.333 and 0.0455). The small group of silver-fir, growing in Białowieża compartment $500 \mathrm{Cj}$ is distinguished by a very high frequency $(\mathrm{p}=0.125)$ of this allele (Table 3). Because there is only one tree capable of bearing seed it is suggested that the young regeneration is the offspring of this one tree.

Lap2 has 4 alleles. One of them, Lap2-1 was found with relatively high frequency (from $17 \%$ in Komańcza to $47 \%$ in Białowieża $\mathrm{Cg}$ ) in all but the Cisovka population, where we found only two alleles of the Lap2 locus.

Esterase (Est 3). Four zones of activity were observed for Est from bud tissue. Only the third zone designated as Est 3 is of interest. In this zone we found 4 electromorphs. One of them, Est3-3, was exceptionally frequent in the Cisovka population, where it reached $\mathrm{p}=0.50$. In other investigated populations, Est $3-3$ was observed with frequencies from 0 to 0.125 .

The frequencies of some alleles are significantly different between the studied populations. The unique population in this sample group is the Cisovka population, distinguished by the highest frequency of the Pgm2-2 and Est3-3 alleles and a very low frequency of Idh1-3 and Lap2-3.

\section{Genetic variation and diversity}

In Table 4 presented are the genetic parameters of the studied populations as follows: 1.) the average number of alleles per locus (Mal), the mean number of alleles per polymorphic locus (Malp) and the percentage of polymorphic loci within populations (Pp) at the $1 \%$ and $5 \%$ criterion. These parameters Mal, Malp and $\mathbf{P p}$ define the genetic variation of a given population. Information is also given on the observed heterozygosity (Hob).

As a measure of genetic diversity Neis expected heterozygosity was used:

He $=1-\Sigma_{j} p^{2} i$

where $p_{i}$ is the frequency of the ith allele in each studied population.

Heterozygosity $\boldsymbol{H}$ - is the frequency of heterozygotic trees in a given population:

\section{$\boldsymbol{H}=\Sigma(N A \boldsymbol{a} / \boldsymbol{N}) / \boldsymbol{n}$}

where $n$ is the number of monomorphic loci and $N$ the number of trees in the population.

The average heterozygosity of the populations was calculated as the arithmetic mean of the proportion of heterozygous individuals in all studied loci (Table 4).

The observed heterozygosities ( $\mathrm{Hob}$ ) ranging from 0.106 in the Komańcza population to 0.150 in the small silver-fir cluster in the 452Bd compartment of Białowieża Forest. The ob- served heterozygosities did not differ significantly from the expected heterozygosity $(\mathrm{He})$ in all but the Cisovka population where there is a significant excess of heterozygotes (Hob $=0.123$ and $\mathrm{He}=0.079$ ). Even if Est-3, a very variable locus is excluded from the calculations, Hob $=0.067$ remains higher than $\mathrm{He}=0.044$. This excess of heterozygosity in the small Cisovka population, is the result of long selection for adaptability to rapidly changing environmental factors in the Białowieża Primeval Forest, after the last glacial period. Heterozygous trees are expected to be more adaptable because natural selection reduces the frequencies of homozygotes in natural forest populations (Stern and Roche 1974).

The Cisovka relic population is a distinct population among the nine silver-fir populations in the UPGMA dendrogram, based on Neis standard genetic distance coefficient (D) (Fig. $5)$. The major branch of the dendrogram separates this population from all others by a great genetic distance $(\mathrm{D}=0.06)$. This indicates a rather great amount of genetic differentiation. Also the two man-made silver-fir stands (B1 and B2) are separated from the others. Only the populations B3 and B4 are combined into one subgroup linked to the population Tomaszów Lubelski.

\section{CONCLUSION}

1. The relic population of Cisovka is threatened by extinction. As shown in Figure 3 its numbers have decreased more than tenfold.

2. Analysis of the allelic frequencies data (Table 3) does not support the hypothesis concerning the origin of the studied artificial silver-fir stands from the Cisovka population.
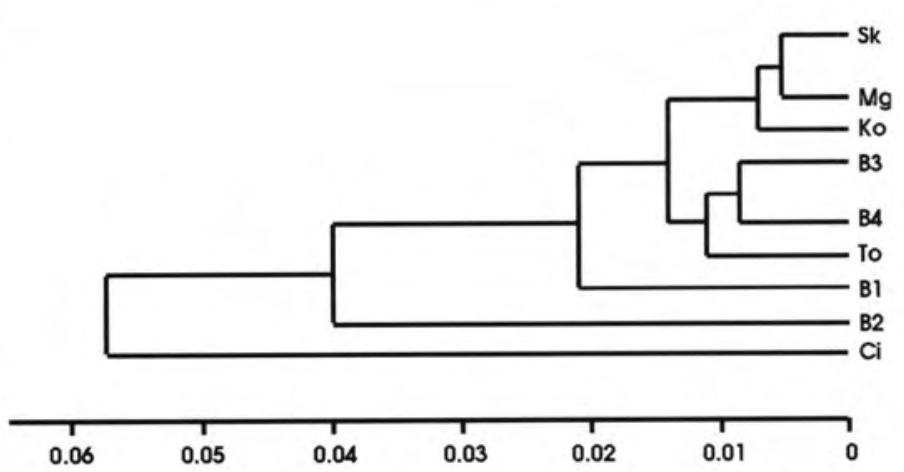

Fig. 5. UPGMA dendrogram based on Neis genetic distance between nine Abies alba provenances 
These stands have large genetic distances to the Cisovka population.

3. These populations are exotic in the Primeval Forest and will genetically pollute the relic Cisovka population.

4. Each of the 11 enzyme systems studied in male-, femaleand vegetative buds exhibited the same enzyme pattern on electrophorogram. With respect to this characteristic there are also no differences between trees of different age.

\section{LITERATURE CITED}

BERGMANN F., GREGORIUS H-R., LARSEN J. B., 1990. Levels and genetic variation in European silver-fir (Abies alba). Genetica 82: 1-10.

BERGMANN F., KOWNATZKI D., 1988. The genetic variation of silver-fir (Abies alba) in Europe monitored from endosperm gene loci. In: Proc. 5. IUFRO-Tannensymposium, Zvolen: 21-26.

BŁONSKI F., DRYMER K., EJSMOND A., 1888. Sprawozdanie z wycieczki botanicznej odbytej do Puszczy Białowieskiej w 1887. Pamiętnik Fizjograficzny 8: 59-74. Warszawa.

BUDNICHENKO, N.I., STRELKOV, A.Z., SALEVICH F.F., MICHALEVICH P.K., 1987. Pichta bielaja v Bialoviezhskoj Pushcie. Zapoviednik Belorus. 11: 13-24.

G. S. (GÓRSKI. S.)., 1829. O roślinach Zubrom upodobanym, jakoteż innych w puszczy Białowiezkiey. Dziennik Wilenski (Umiejętności i Sztuki) 4: 207-217. A. Marcinkowski, Wilno.

GUNIA, S., KOWALSKI M., 1968: Jodła pospolita (Abies alba Mill.) w Puszczy Białowieskiej. Sylwan CXII (3): 59-66.

HUSSENDÖRFER E., KONNERT M., BERGMANN F. 1995: Inheritance and linkage of isozyme variants of silver-fir (Abies alba Mill.). Forest Genetics 2 (2): 29-40.

KLOSKA, J., 1922. Nowe stanowisko jodły w Puszczy Białowieskiej. Las Polski. 10: 383-385.

KONNERT, M., BERGMANN, F., 1995. The geographical distributionrelation to its migration history. Plant Syst. Evol. 196: 19-30.

KORCZYK, A., CHILIMONIUK, M., 1993. Jodła w Puszczy Białowieskiej. Las Polski. 10: 14-16.

KORMUTAK A., BENçAT F., RUDIN D., SEYEDYAZDANI R., 1982. Isoenzyme variation in the four Slovakian populations of Abies alba Mill. Biologia 37 (5): 433-440.

LEWANDOWSKI A., MEJNARTOWICZ L., 1994. Detection of close linkage between glutamate and isocitrate dehydrogenase allozyme loci in Picea abies. Hereditas 120: 281-292.

LEWANDOWSKI A., MEJNARTOWICZ L., BURCZYK J., 1995. Genetic structure of English yew (Taxus baccata L.) in the Wierz- chlas Reserve: implications for genetic conservation. Forest Ecology and Management 73: 221-227.

LONGAUER, R., 1994. Genetic differentiation and diversity of the European silver-fir in the eastern part of its natural range. Proceedings of the 7. IUFRO Weisstannen-Symposium, Ökologie und Waldbau der Weisstanne, 31-10- 3.11.1994, Altensteig, Germany: 155-163.

MEJNARTOWICZ L. 1979. Polymorphism at the LAP and GOT loci in Abies alba Mill. populations. Bulletin de l'Academie Polon. des Scie. 27(12): 1063-1070.

MEJNARTOWICZ L. 1983. Genetyka. In: Białobok S. (ed.). Jodła (Abies alba Mill.). Monografie: Nasze Drzewa Leśne. PWN Warszawa-Poznań 4: 285-316.

MEJNARTOWICZ L., BERGMANN F. 1985. Genetic differentiation among Scots pine populations from lowlands and the mountains in Poland. In: Gregorius G-R. (ed.). Lecture Notes in Biomathematics 60: 242-252. Springer Verlag, Berlin- N.Y.-Tokyo.

MEJNARTOWICZ L., LEWANDOWSKI A. 1995. Dynamika populacji jodły pospolitej (Abies alba Mill.) w silnie zanieczyszczonym środowisku Sudet. In: Mirek Z., Wójcicki J.J. (eds.) Szata roślinna Polski w procesie przemian. Materiały konferencji i sympozjów 50 Zjazdu PTB. Kraków 26.06-01.07.1995: 259.

MEJNARTOWICZ L., LEWANDOWSKI A., BERGMANN F., 1994. Genetic structure and variation of the European silver-fir populations at man-made range disjunction. In: Eder W. (ed.) Proc. of the 7. IUFRO Tannensymposium der WP S. 1.01-08, Ökologie und Waldbau der Weisstanne, 31-10- 3.11.1994. Altensteig, Germany: 118-127.

NEI M., 1975. Molecular population genetics and evolution. Elsevier, N.Y.

PACZOSKI J., 1928. Lasy Białowieży. Państwowa Rada Ochrony Przyrody. Poznań.

PITEL J. A, CHELIAK W. M., 1984 Effect of extraction buffers on characterization of isoenzymes of five conifer species: A users manual. PI-X-34, Petawawa Nation. Forest. Inst.: 60.

POULIK M. D. 1957. Starch gel electrophoresis in a discontinuous system of buffers. Nature 180: 1477-1478.

RIDGEWAY G.J., SHERBURNE S.W., LEWIS R.D., 1970. Polymorphism in esterase of Atlantic herring. Trans. Am. Fish. Soc. 99: 147-151.

SCHRÖDER S., 1989. Isozyme polymorphisms in silver-fir (Abies alba Mill.). Silvae Gen. 38(3-4): 130-133.

SHKUTKO, N.W., MARTINOVICH, V.S. 1967. Pikhta bielaja v Bielarussii. In: Dendrologia i lesovedenije. Nauka i Tekhnika, Minsk.

STERN K., ROCHE L. 1974: Genetics of Forest ecosystems. SpringerVerlag, Berlin.

SZAFER W. 1920: Jodła w Puszczy Białowieskiej. Sylwan XXXVIII (7-9): 65-74.

SZAFER W. 1920a.: Plan utworzenia rezerwatu leśnego w Puszczy Białowieskiej. Sylwan XXXVIII (10-12): 97-117. 


\section{CISOVKA - RELIKTOWA POPULACJA ABIES ALBA I JEJ POKREWIEŃSTWO ZE SZTUCZNYMI DRZEWOSTANAMI JODŁOWYMI W PUSZCZY BIAŁOWIESKIEJ}

\section{STRESZCZENIE}

W 1823 Stanisław Górski odkrył w Puszczy Białowieskiej reliktową populację Abies alba Mill. na ostrowiu Cisovka. Jest ona oddalona o $120 \mathrm{~km}$ na północny wschód od granicy ciągłego zasięgu występowania jodły zwyczajnej. Obok naturalnej populacji Cisovka, są również sztuczne drzewostany i kępy jodłowe, zarówno w polskiej jak i białoruskiej części Puszczy. W polskiej części są 4 sztuczne drzewostany jodłowe. Jeżeli drzewostany te, wykształcające nasiona, są rzeczywiście proweniencji Cisovka, to są one cenną frakcją ginącej populacji oraz łatwo dostępnym źródłem nasion. Jeśli jednak populacje te są intrudkowanymi do Puszczy Białowieskiej, to są one potencjalnym źródłem niebezpiecznego, genetycznego, zanieczyszczenia populacji Cisovka. Wzajemne relacje struktury genetycznej populacji Cisovka do sztucznych drzewostanów jodłowych istniejących w Nadleśnictwie Białowieża, badano z pomocą 17 loci z 11 systemów enzymowych. Genetyczną różnorodność populacji Cisovka charakteryzuje najmniejsza średnia liczba alleli w locus $(\mathrm{Mal}=1,353$, z wszystkich badanych loci i dla loci polimorficznych Malp $=2.00)$. W populacji Cisovka jest także bardzo mało polimorficznych loci $(P p=11,765$, przy średniej ze wszystkich badanych populacji 37,225). Oczekiwana heterozygotyczność, $\mathrm{He}=0,079$ ujawnia bardzo niski poziom genetycznego zróżnicowania wewnątrzpopulacyjnego. Heterozygotyczność obserwowana w populacji $(H o=0,123)$ była podobna do wartości tej cechy w innych populacjach. Na podstawie współczynników dystansu genetycznego (D) Neiego utworzono dendrogram dla 9 badanych populacji jodły zwyczajnej. W dendrogramie UPGMA populacja Cisovka jest oddzielona od pozostałych populacji bardzo dużym dystansem genetycznym $(\mathrm{D}=0.06)$. Również dwa sztuczne drzewostany jodłowe (B1 i B2) oddzielone są od pozostałych. Tylko drzewostan B3 łączy się w jedną grupę z populacją Tomaszów Lubelski. Na podstawie otrzymanych wyników można sądzić, że cztery sztuczne drzewostany jodłowe są introdukowanymi do Puszczy Białowieskiej. Istnieje pewna podstawa do przypuszczeń, oparta na częstości alleli GDH2, że drzewostany z oddziałów 453Aa i 498Cg są wschodnich proweniencji. Jest raczej pewnym, że drzewostany te nie są potomstwem populacji Cisovka.

KEY WORDS: Abies alba, izoenzymy, ochrona populacji. 